\title{
Triaxial experiments on iceberg and glacier ice
}

\author{
R. E. GAGNON \\ Institute for Marine Dynamics, National Research Council of Canada, St. John's, Newfoundland A1B 3T.5, Canada \\ P. H. GAMMON \\ Consolidated Technologies Limited, 37 Stavanger Drive, St. John's, Newfoundland A1A 5E8, Canada
}

\begin{abstract}
Triaxial experiments, at confining pressures in the range 0 13.79 $\mathrm{MPa}$, have been performed on glacial ice collected from four icebergs and one glacier. Tests were conducted at strain rates in the range of $5 \times 10^{-5}$ to $5 \times 10^{-2} \mathrm{~s}^{-1}$ and at four temperatures in the range of $-1^{\circ}$ to $-16^{\circ} \mathrm{C}$. Depending on test conditions, the ice failed by one of four possible modes: ductile deformation, due to extensive noninteracting microcracks; fracture along a shear plane followed by continuous or stickslip sliding; large-scale brittle fracture; and combined ductile and shear-plane fracture and slip. The strength increased with decreasing temperature, increasing strain rate up to $5 \times 10^{-3} \mathrm{~s}^{-1}$ and increasing confining pressure at the lower temperatures. The strength at $5 \times 10^{-2} \mathrm{~s}^{-1}$ was lower than at $5 \times 10^{-3} \mathrm{~s}^{-1}$ probably because extension and interaction of microcracks is enhanced at the higher rate. For higher confining pressures at $-1{ }^{\circ} \mathrm{C}$, the strength decreased due to freezing-point depression. The ice from the different sources exhibited different mean uniaxial compressive strengths. The mean number of air bubbles per unit volume correlated with the mean uniaxial compressive strengths and this may be the dominant factor distinguishing the strengths of the various ice types.
\end{abstract}

\section{INTRODUCTION}

Icebergs pose a serious hazard for operations of ships and offshore structures in cold oceanic regions, including the North Atlantic Ocean. In 1981-82, Mobil Oil Corporation, recognizing the possibility of impacts with icebergs, funded the first phase of a major research program to study the physical and mechanical properties of iceberg ice. The aim was to assess the structural requirements for offshore resource development off the east coast of Canada. The study involved the collection of large quantities of ice from a grounded iceberg in Labrador and smaller amounts from three icebergs in Greenland and a Greenland glacier. Impact tests, triaxial tests and beam-bending experiments were performed on the ice in the laboratory. The data from the beam-bending experiments, including an explanation for the observed differences in flexural strength between the ice from the five different sources, has been published (Gagnon and Gammon, 1995). This paper reports the results from the triaxial component of the test program and the data analysis supports the previous explanation for observed differences in ice strength.

\section{SPECIMEN PREPARATION}

The field program for the collection of the ice, and the transportation of the ice to the laboratory, has been described in detail (Gagnon and Gammon, 1995).
Labrador ice specimens used for triaxial testing were initially cored from the remaining corners of Labrador ice blocks after impact specimens had been extracted. A thermal-coring device was utilized to produce a cylinder of diameter $9.58 \mathrm{~cm}$ and approximately $26 \mathrm{~cm}$ length from each corner. Greenland triaxial specimens were extracted from full-size blocks of Greenland ice. All specimens were given flat end faces by quick application to warm metallic plates while lodged inside a jig which insured that the ends were mutually parallel. Samples were then removed from the jig, placed in plastic bags with most of the air expelled and laid in storage at a temperature of approximately $-26^{\circ} \mathrm{C}$.

\section{APPARATUS}

The first ten uniaxial tests were performed on a smallcapacity MTS load frame equipped with a $111.2 \mathrm{kN}$ servo ram.

All other experiments were carried out on a larger load frame designed by university technicians and equipped with a $667.2 \mathrm{kN}$ MTS servo ram. Both systems were powered by an MTS hydraulic supply pump which could deliver $1.52 \mathrm{~L} \mathrm{~s}^{-1}$ at $20.70 \mathrm{MPa}$.

The confinement cell (Structual Behaviour Engineering Laboratories Inc., Triaxial Cell No. 6-12) was rated for $68.95 \mathrm{MPa}$ internal pressure and equipped with electrical ports so that specimens could be instrumented inside the cell if necessary. The head of the cell was fitted 
with a piston ram (Fig. 1) so that uniaxial stress could be applied to specimens inside the cell simultaneously with the hydrostatic stress applied to the sample through the separately controlled triaxial confinement fluid. In order to conduct experiments at the required temperatures in the laboratory where the large loading frame was situated, it was necessary to incorporate a refrigeration unit into the system. This was accomplished by winding the cooling coils of the refrigeration unit around the cell and thermally insulating it from warm air at ambient room temperature. In this manner, the confinement cell temperature was thermostatically controlled and set to the desired level $\left( \pm 1^{\circ} \mathrm{C}\right)$ without requiring the use of a cold room. For both the smaller and larger load-frame set-ups, it was intended that tests be carried out at constant strain rates. Ram position versus time was controlled by use of a function generator. Constant ram speed was established by using a linear ramp function of specified height (span) and duration as the control signal.

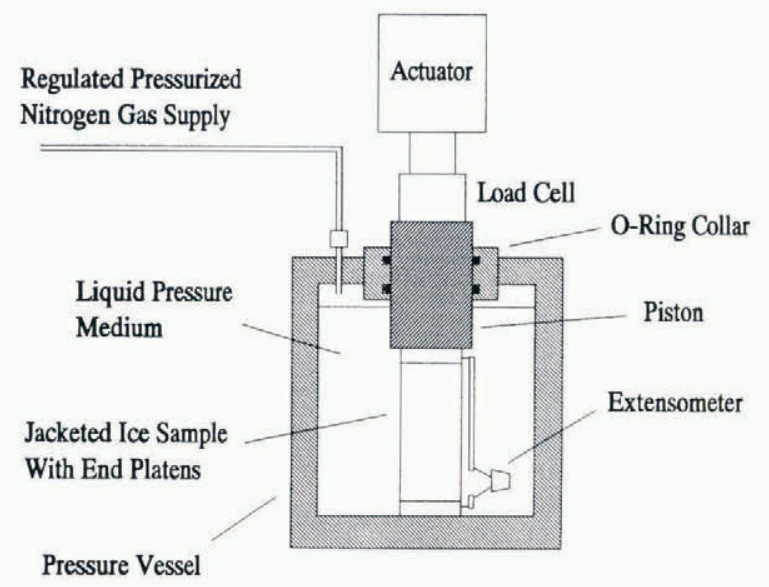

Fig. 1. Experimental set-up for triaxial confinement tests. External cooling coils and insulating material for the confinement vessel are not shown.

The nominal strain rate for a given test was determined from the linear part of the strain vs time curve for the specimen just prior to failure. The axial strain was measured over the full length of a specimen by means of an extensometer (Fig. 1) fitted with extended arms, so that they could be attached to the upper and lower platens which had been frozen to the sample ends. On the smaller apparatus, the extensometer output was converted to $0-10 \mathrm{~V}$ format via an adapted conditioning module (MTS 440.2 d.c. conditioner) before transfer to the data-acquisition system. For the larger load-frame apparatus, a Daytronic model 770 conditioner was used. Strain measurements were accurate to within $\pm 1 \%$ before any violent events, such as large-scale fracture, occurred during a test. These events caused sudden displacement at one end of a sample that would result in slippage of the extensometer arms on the end platens and disturbance of the orientation of the extensometer. Subsequent strain data would qualitatively reflect the behaviour of the ice but the absolute accuracy would be less than it was before the violent events.

Throughout the course of the program, two separate load cells were used to determine axial stress applied to the specimens. Initially, a flat load cell (Strainsert model FL 25U-2SG; $111.2 \mathrm{kN}$ ) was situated inside the triaxial cell and specimens rested directly on it in a vertical position. Part way through the test program, however, this cell malfunctioned and an external load cell $(445 \mathrm{kN}$, Schaevitz Engineering, model FTA-6C-100K) was positioned between the load-frame ram and the cell piston. The use of an external load cell necessitated zeroing loads resulting from the triaxial cell's internal fluid pressure before commencing tests. This was accomplished by using the load cell's conditioning module (Daytronic model 770 ). During tests, the output from the load cell was transmitted directly to the data-acquisition system after conditioning. The data-acquisition system was interfaced with a HP85 computer which stored the data in appropriately designated files on magnetic tape. Besides recording each data set on magnetic tape, a graphic record was obtained by utilizing an $\mathrm{X}-\mathrm{Y}-\mathrm{Y}$ chart recorder connected in parallel with the data-acquisition system to give an immediate visual display of each test for convenient confirmation of text quality.

\section{TEST PROCEDURE}

Prior to testing, each ice specimen was taken from storage and cylindrical copper platens $102 \mathrm{~mm}$ diameter, $16 \mathrm{~mm}$ thick) were frozen to its ends. First, the specimen was placed in a snug-fitting jig and then laid end down on to one of the slightly warmed platens which was then allowed to freeze to the specimen. In this fashion, any irregularities between ice and platen were entirely eliminated by melting. The jig insured that the specimen axis was normal to the platen face. Next, the specimen was removed from the jig and laid platen-down on to a horizontal table. The second copper platen was then melted on to the top while using a level to insure parallelness between ends. Next, two snug-fitting rubber sleeves (M \& L Testing Equipment Co. Ltd, model WF 11090 were slid over the specimen and secured to the platens with elastic bands. These membranes prevented the triaxial confining fluid from coming into direct contact with the ice during testing. This procedure took place at a commercial cold-room facility. The specimen was then transported in a thermally insulated container to Memorial University's Faculty of Engineering ready to be placed inside the triaxial confinement cell.

When the ice arrived at M.U.N. Faculty of Engineering, the extensometer arms were quickly secured to the specimen at the platens with elastic bands and then the fully prepared sample was carefully lowered into the triaxial confinement cell to rest on a specially constructed seat designed to center the specimen relative to the piston head of the cell. The head of the cell was then screwed on and the specimen was allowed to thermalize (approximately $40 \mathrm{~min}$ ) to the temperature of the confinement cell. Before pressurization of the cell, the load-frame ram was brought into contact with the confinement-cell piston and carefully moved downward until contact was lightly 
established with the ice specimen inside. Contact was immediately discernible from the digital displays of strain and load. Confinement fluid (fluorocarbon refrigerant) completely filled the confinement chamber except for a small space at the top (Fig. 1), which was connected via high-pressure tubing to a bottle of compressed nitrogen gas equipped with a regulator so that confining pressure inside the cell could be adjusted by simply choosing the appropriate regulator setting. Confining pressure was accurate to within $\pm 1 \%$. After pressurization of the confinement cell, the ram and piston were backed off slightly from contact with the ice. During a test, this made it possible to observe and account for the friction due to the O-ring seals in the confinement cell's head, since the frictional force would appear as a distinct inflection in the load vs time curve before specimen contact had been established. Load measurements were accurate to within $\pm 1 \%$. O-ring friction did not affect results when the internal load cell was still in working order, since the internal cell registered only the stress directly on the specimen. After the ram and piston had been backed off, proper settings were selected for ram stroke and duration, and the start button was pressed to commence the test.

After a test had been completed, the head of the confinement cell was removed and the sample with platens still attached was taken out. The platens and rubber membranes were then removed and the sample was placed in storage to await photographic documentation of its failure mode.

\section{TEST SEQUENCE}

A total of 132 triaxial tests was performed during this program. One hundred Labrador and 32 Greenland ice samples were tested. The triaxial test parameters and mode of specimen failure are given in Table 1. In addition, a statistical summary of the triaxial tests is presented in Table 2. In the tables, tests on Labrador ice are listed before tests on Greenland ice. The ordering of the tests is first by decreasing temperature then, for tests at the same temperature, by increasing confining pressure and then, for tests at the same temperature and confining pressure by decreasing strain rate.

\section{REPRESENTATIVE TRIAXIAL TEST}

The plots of stress minus cell pressure vs time and axial strain vs time, which make up Figure 2, represent a typical triaxial test (test 24.3) on a Greenland ice specimen conducted at $-11^{\circ} \mathrm{C}$ with a confining pressure of $3.45 \mathrm{MPa}$ at a strain rate of $2.3 \times 10^{-3} \mathrm{~s}^{-1}$. The stress curve began at a value slightly less than zero. Then, after the ram started moving, but before the confinement-cell piston actually contacted the ice, stress increased slightly to a plateau which was defined as zero and which corresponded to the friction of the O-rings in the head of the confinement cell. This small inflection on the stress curve, due to O-ring friction, was present only when the externally mounted load cell was utilized, since the internal load cell, when it was functional, measured only stress on the ice specimen. The stress rose rapidly and

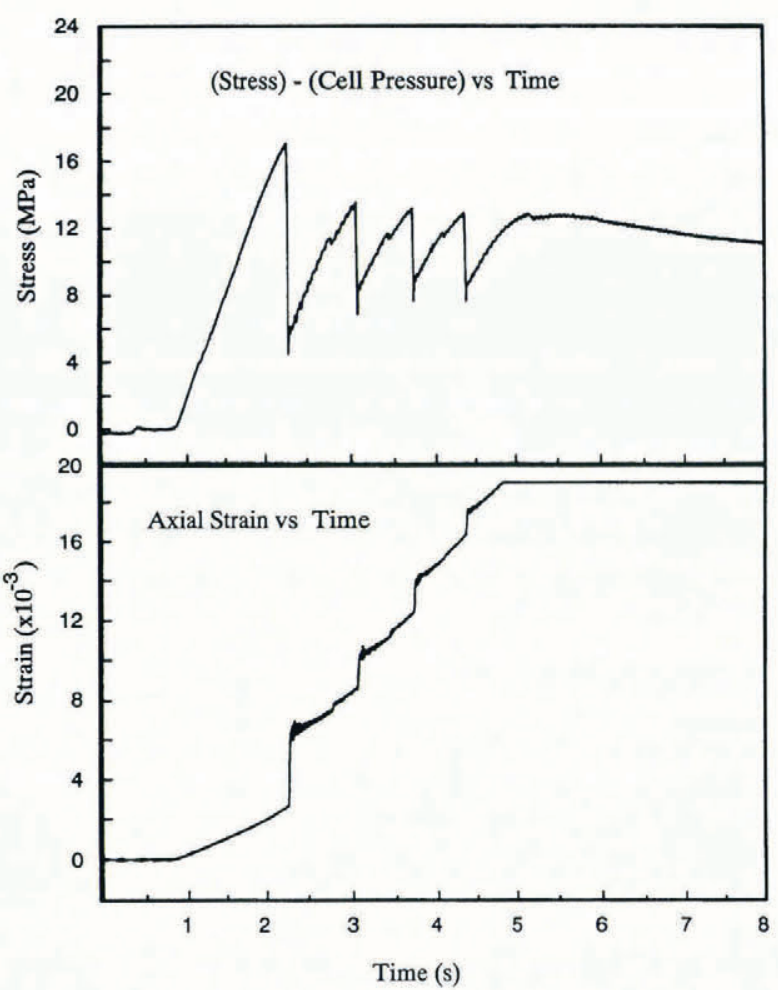

Fig. 2. Plots of stress minus cell pressure vs time and axial strain vs time for triaxial test No. 24.3. The test was conducted at a strain rate of $2.3 \times 10^{-3} \mathrm{~s}^{-1}$ on Greenland ice at a temperature of $-11^{\circ} \mathrm{C}$ and a confining pressure of $3.45 \mathrm{MPa}$.

linearly when the piston head made contact with the ice specimen. A maximum then occurred in stress, at which point the specimen fractured and slipped along a shear plane. The sudden forward motion of the actuator, implied in the strain record, led to relief of some of the elastic stress that had built up in the apparatus and ice. Stress immediately rose again until another abrupt slip occurred, and then another and so on. Ductile flow also began to occur as the test progressed. This was manifested by the decreasing slope of the stress curve which became more pronounced until finally towards the end of the test no further abrupt shear slips resulted and a plateau was reached, signifying that ductile flow and perhaps some smooth continuous shear slipping was responsible for the ice deformation. The strain vs time plot reflected perfectly all the rises and abrupt changes which were present in the stress plot. The strain reading reached a plateau after approximately $5 \mathrm{~s}$. Thereafter, the reading was no longer meaningful because the extensometer arms had been extended to their limit.

\section{RESULTS AND DISCUSSION}

\section{Failure modes}

Mechanical failure of any particular ice specimen in the program could be described by one of four possible modes (Fig. 3). The first was brittle fracture. One manifestation of this was axial cleavage (Fig. 3a), where the sample broke along one or more cracks which usually ran along 
Gagnon and Gammon: Triaxial experiments on iceberg and glacier ice

Table 1. Triaxial test parameters. Key: ${ }^{*} F$, fracture; P/SS, plastic/shear-slip; P, plastic; SS, shear-slip

\begin{tabular}{|c|c|c|c|c|c|c|c|c|c|c|c|}
\hline $\begin{array}{l}\text { Test } \\
\text { No. }\end{array}$ & $\begin{array}{l}\text { Strength } \\
\mathrm{MPa}\end{array}$ & $\begin{array}{c}\text { Confining } \\
\text { pressure } \\
\mathrm{MPa}\end{array}$ & $\begin{array}{c}\text { Temperature } \\
{ }^{\circ} \mathrm{C}\end{array}$ & $\begin{array}{l}\text { Strain rate } \\
\times 10^{-3} \mathrm{~s}^{-1}\end{array}$ & $\begin{array}{l}\text { Failure } \\
\text { mode }\end{array}$ & $\begin{array}{l}\text { Test } \\
\text { No. }\end{array}$ & $\begin{array}{l}\text { Strength } \\
\mathrm{MPa}\end{array}$ & $\begin{array}{l}\text { Confining } \\
\text { pressure } \\
\mathrm{MPa}\end{array}$ & $\begin{array}{c}\text { Temperature } \\
{ }^{\circ} \mathrm{C}\end{array}$ & $\begin{array}{l}\text { Strain rate } \\
\times 10^{-3} \mathrm{~s}^{-1}\end{array}$ & $\begin{array}{l}\text { Failure } \\
\text { mode }\end{array}$ \\
\hline \multicolumn{12}{|c|}{ Labrador ice } \\
\hline 1.1 & 4.18 & 0.00 & -1 & 1.61 & $\mathrm{~F}$ & 14.5 & 15.02 & 6.89 & -11 & 36.80 & SS \\
\hline 1.2 & 3.40 & 0.00 & -1 & 3.33 & $\mathrm{~F}$ & 15.1 & 15.64 & 6.89 & -11 & 4.61 & $\mathrm{P} / \mathrm{SS}$ \\
\hline 1.3 & 3.64 & 0.00 & -1 & 0.69 & $\mathrm{~F}$ & 15.2 & 15.79 & 6.89 & -11 & 4.58 & $\mathrm{P}$ \\
\hline 1.4 & 5.65 & 0.00 & -1 & 1.52 & $\mathrm{~F}$ & 15.3 & 16.86 & 6.89 & -11 & 4.38 & $\mathrm{P} / \mathrm{SS}$ \\
\hline 1.5 & 5.28 & 0.00 & -1 & 0.80 & $\mathrm{~F}$ & 15.4 & 16.85 & 6.89 & -11 & 3.33 & $\mathrm{P} / \mathrm{SS}$ \\
\hline 2.1 & 11.10 & 1.38 & -1 & 3.84 & $\mathrm{P} / \mathrm{SS}$ & 15.5 & 15.11 & 6.89 & -11 & 4.19 & $\mathrm{P} / \mathrm{SS}$ \\
\hline 2.2 & 10.40 & 1.38 & -1 & 4.26 & $\mathrm{P}$ & 16.1 & 4.27 & 6.89 & -11 & 0.0578 & $\mathrm{P}$ \\
\hline 2.3 & 9.53 & 1.38 & -1 & 3.99 & $\mathrm{P} / \mathrm{SS}$ & 16.2 & 5.08 & 6.89 & -11 & 0.0612 & $\mathrm{P}$ \\
\hline 2.4 & 9.67 & 1.38 & -1 & 3.76 & $\mathrm{P} / \mathrm{SS}$ & 16.3 & 5.00 & 6.89 & -11 & 0.0594 & $\mathrm{P}$ \\
\hline 2.5 & 10.77 & 1.38 & -1 & 3.78 & $\mathrm{P} / \mathrm{SS}$ & 16.4 & 4.90 & 6.89 & -11 & 0.0677 & $\mathrm{P}$ \\
\hline 3.1 & 10.69 & 3.45 & -1 & 4.07 & $\mathrm{P}$ & 16.5 & 4.50 & 6.89 & -11 & 0.0518 & $\mathrm{P}$ \\
\hline 3.2 & 11.22 & 3.45 & -1 & 4.55 & $\mathrm{P}$ & 17.1 & 16.28 & 13.79 & -11 & 183.00 & SS \\
\hline 3.3 & 10.34 & 3.45 & -1 & 4.29 & $\mathrm{P}$ & 17.2 & 15.09 & 13.79 & -11 & 202.00 & SS \\
\hline 3.4 & 9.90 & 3.45 & -1 & 4.36 & $\mathrm{P}$ & 17.3 & 14.64 & 13.79 & -11 & 38.30 & SS \\
\hline 3.5 & 8.71 & 3.45 & -1 & 4.41 & $\mathrm{P} / \mathrm{SS}$ & 17.4 & 15.97 & 13.79 & -11 & 25.60 & SS \\
\hline 4.1 & 10.82 & 6.89 & -1 & 5.21 & $\mathrm{P}$ & 17.5 & 12.88 & 13.79 & -11 & 137.00 & SS \\
\hline 4.2 & 12.55 & 6.89 & -1 & 4.59 & $\mathrm{P}$ & 18.1 & 16.88 & 13.79 & -11 & 5.15 & $\mathrm{P}$ \\
\hline 4.3 & 10.29 & 6.89 & -1 & 4.96 & $\mathrm{P} / \mathrm{SS}$ & 18.2 & 15.41 & 13.79 & -11 & 5.15 & $\mathrm{P}$ \\
\hline 4.4 & 10.16 & 6.89 & -1 & 4.69 & $\mathrm{P}$ & 18.3 & 16.23 & 13.79 & -11 & 5.14 & $\mathrm{P}$ \\
\hline 4.5 & 9.87 & 6.89 & -1 & 4.76 & $\mathrm{P}$ & 18.4 & 15.43 & 13.79 & -11 & 5.94 & $\mathrm{P}$ \\
\hline 5.1 & 8.00 & 13.79 & -1 & 5.28 & $\mathrm{P}$ & 18.5 & 16.10 & 13.79 & -11 & 6.97 & $\mathrm{P}$ \\
\hline 5.2 & 8.92 & 13.79 & -1 & 5.23 & $\mathrm{P}$ & 19.1 & 19.16 & 1.38 & -16 & 5.20 & $\mathrm{P} / \mathrm{SS}$ \\
\hline 5.3 & 8.08 & 13.79 & -1 & 5.43 & $\mathrm{P}$ & 19.2 & 19.48 & 1.38 & -16 & 4.42 & $\mathrm{P}$ \\
\hline 5.4 & 9.33 & 13.79 & -1 & 4.32 & $\mathrm{P}$ & 19.3 & 17.22 & 1.38 & -16 & 3.26 & $\mathrm{P} / \mathrm{SS}$ \\
\hline 5.5 & 9.02 & 13.79 & -1 & 5.38 & $\mathrm{P}$ & 19.4 & 19.34 & 1.38 & -16 & 4.25 & $\mathrm{P}$ \\
\hline 6.1 & 12.76 & 1.38 & -6 & 4.20 & $\mathrm{P}$ & 19.5 & 16.89 & 1.38 & -16 & 2.84 & $\mathrm{P} / \mathrm{SS}$ \\
\hline 6.2 & 12.84 & 1.38 & -6 & 4.26 & $\mathrm{P}$ & 20.1 & 21.32 & 6.89 & -16 & 5.32 & $\mathrm{P}$ \\
\hline 6.3 & 10.62 & 1.38 & -6 & 2.34 & $\mathrm{P} / \mathrm{SS}$ & 20.2 & 20.86 & 6.89 & -16 & 4.68 & $\mathrm{P} / \mathrm{SS}$ \\
\hline 6.4 & 12.85 & 1.38 & -6 & 3.67 & $\mathrm{P}$ & 20.3 & 17.56 & 6.89 & -16 & 7.88 & $\mathrm{P} / \mathrm{SS}$ \\
\hline 6.5 & 12.28 & 1.38 & -6 & 4.34 & $\mathrm{P}$ & 20.4 & 21.97 & 6.89 & -16 & 4.58 & $\mathrm{P}$ \\
\hline 7.1 & 14.58 & 6.89 & -6 & 4.41 & $\mathrm{P}$ & 20.5 & 16.86 & 6.89 & -16 & 5.40 & $\mathrm{P} / \mathrm{SS}$ \\
\hline 7.2 & 12.23 & 6.89 & -6 & 4.86 & $\mathrm{P} / \mathrm{SS}$ & \multicolumn{6}{|c|}{ Greenland 1 ice } \\
\hline 7.3 & 13.20 & 6.89 & 6 & 4.78 & $\mathrm{P} / \mathrm{SS}$ & 21.1 & 8.44 & 0.00 & -11 & 1.58 & $\mathrm{~F}$ \\
\hline 7.4 & 13.06 & 6.89 & -6 & 4.65 & $\mathrm{P}$ & 21.2 & 9.33 & 0.00 & -11 & 1.38 & $\mathrm{~F}$ \\
\hline 7.5 & 13.03 & 6.89 & -6 & 4.93 & $\mathrm{P}$ & 21.3 & 8.71 & 0.00 & -11 & 1.60 & $\mathrm{~F}$ \\
\hline 8.1 & 9.73 & 0.00 & -11 & 1.68 & $\mathrm{~F}$ & 21.4 & 8.05 & 0.00 & -11 & 1.23 & $\mathrm{~F}$ \\
\hline 8.2 & 5.22 & 0.00 & -11 & 1.24 & $\mathrm{~F}$ & 22.1 & 16.26 & 3.45 & -11 & 4.82 & $\mathrm{P}$ \\
\hline 8.3 & 8.17 & 0.00 & -11 & 1.39 & F & 22.2 & 15.94 & 3.45 & -11 & 2.88 & $\mathrm{P} / \mathrm{SS}$ \\
\hline 8.4 & 7.80 & 0.00 & -11 & 1.76 & $\mathrm{~F}$ & 22.3 & 14.98 & 3.45 & -11 & 3.12 & $\mathrm{P} / \mathrm{SS}$ \\
\hline 8.5 & 8.20 & 0.00 & -11 & 2.07 & $\mathrm{~F}$ & 22.4 & 16.45 & 3.45 & -11 & 4.16 & P \\
\hline 9.1 & 10.79 & 1.38 & -11 & 98.60 & SS & \multirow{2}{*}{\multicolumn{6}{|c|}{ Greenland 2 ice }} \\
\hline 9.2 & 10.72 & 1.38 & -11 & 82.70 & SS & & & & & & \\
\hline 9.3 & 10.84 & 1.38 & -11 & 66.90 & SS & 23.1 & 6.66 & 0.00 & -11 & 1.49 & $\mathrm{~F}$ \\
\hline 9.4 & 9.50 & 1.38 & -11 & 51.90 & SS & 23.2 & 7.26 & 0.00 & -11 & 1,46 & $\mathrm{~F}$ \\
\hline 9.5 & 11.88 & 1.38 & -11 & 87.30 & SS & 23.3 & 7.96 & 0.00 & -11 & 1.33 & $\mathrm{~F}$ \\
\hline 10.1 & 14.61 & 1.38 & -11 & 3.88 & $\mathrm{P} / \mathrm{SS}$ & 23.4 & 7.23 & 0.00 & -11 & 1.86 & $\mathrm{~F}$ \\
\hline 10.2 & 15.11 & 1.38 & -11 & 5.24 & $\mathrm{P}$ & 24.1 & 17.14 & 3.45 & -11 & 2.39 & $\mathrm{P} / \mathrm{SS}$ \\
\hline 10.3 & 14.02 & 1.38 & -11 & 4.39 & $\mathrm{P}$ & 24.2 & 16.94 & 3.45 & -11 & 3.38 & $\mathrm{P} / \mathrm{SS}$ \\
\hline 10.4 & 13.60 & 1.38 & -11 & 2.5 .4 & $\mathrm{P} / \mathrm{SS}$ & 24.3 & 16.88 & 3.45 & -11 & 2.30 & $\mathrm{P} / \mathrm{SS}$ \\
\hline 10.5 & 15.86 & 1.38 & -11 & 1.27 & $\mathrm{P}$ & 24.4 & 16.87 & 3.45 & -11 & 2.16 & $\mathrm{P} / \mathrm{SS}$ \\
\hline 11.1 & 3.40 & 1.38 & -11 & 0.0422 & $\mathrm{P}$ & \multirow{2}{*}{\multicolumn{6}{|c|}{ Greenland 3 ice }} \\
\hline 11.2 & 3.20 & 1.38 & -11 & 0.0441 & $\mathrm{P}$ & & & & & & \\
\hline 11.3 & 3.72 & 1.38 & -11 & 0.0514 & $\mathrm{P}$ & 25.1 & 6.61 & 0.00 & -11 & 1.23 & $\mathrm{~F}$ \\
\hline 11.4 & 3.63 & 1.38 & -11 & 0.0449 & $\mathrm{P}$ & 25.2 & 7.67 & 0.00 & -11 & 1.13 & $\mathrm{~F}$ \\
\hline 11.5 & 3.56 & 1.38 & -11 & 0.0582 & $\mathrm{P}$ & 25.3 & 8.10 & 0.00 & -11 & 1.20 & $\mathrm{~F}$ \\
\hline 12.1 & 12.29 & 3.45 & -11 & 71.90 & $\mathrm{SS}$ & 25.4 & 7.39 & 0.00 & -11 & 1.03 & F \\
\hline 12.2 & 12.32 & 3.45 & -11 & 92.20 & SS & 26.1 & 19.04 & 3.45 & -11 & 2.29 & $\mathrm{P} / \mathrm{SS}$ \\
\hline 12.3 & 11.37 & 3.45 & -11 & 52.00 & SS & 26.2 & 18.81 & 3.45 & -11 & 2.19 & $\mathrm{P} / \mathrm{SS}$ \\
\hline 12.4 & 13.59 & 3.45 & -11 & 85.70 & $\mathrm{SS}$ & 26.3 & 18.32 & 3.45 & -11 & 1.73 & $\mathrm{P} / \mathrm{SS}$ \\
\hline 12.5 & 10.33 & 3.45 & -11 & 264.00 & SS & 26.4 & 17.52 & 3.45 & -11 & 1.86 & SS \\
\hline 13.1 & 14.20 & 3.45 & -11 & 3.74 & $\mathrm{P} / \mathrm{SS}$ & \multicolumn{6}{|c|}{ Greenland 4 ice } \\
\hline 13.2 & 15.49 & 3.45 & -11 & 3.07 & $\mathrm{P} / \mathrm{SS}$ & 27.1 & 12.14 & 0.00 & -11 & 1.68 & $\mathrm{~F}$ \\
\hline 13.3 & 11.59 & 3.45 & -11 & 5.81 & $\mathrm{P} / \mathrm{SS}$ & 27.2 & 11.72 & 0.00 & -11 & 1.75 & $\mathrm{~F}$ \\
\hline 13.4 & 13.55 & 3.45 & -11 & 4.90 & P & 27.3 & 10.05 & 0.00 & -11 & 1.27 & $\mathrm{~F}$ \\
\hline 13.5 & 11.10 & 3.45 & -11 & 3.33 & $\mathrm{P} / \mathrm{SS}$ & 27.4 & 10.44 & 0.00 & -11 & 1.44 & $\mathrm{~F}$ \\
\hline 14.1 & 15.25 & 6.89 & -11 & 84.40 & SS & 28.1 & 17.14 & 3.45 & -11 & 2.02 & $\mathrm{P} / \mathrm{SS}$ \\
\hline 14.2 & 11.14 & 6.89 & -11 & 83.80 & SS & 28.2 & 13.03 & 3.45 & -11 & 1.75 & SS \\
\hline 14.3 & 14.95 & 6.89 & -11 & 68.10 & SS & 28.3 & 19.26 & 3.45 & -11 & 2.20 & $\mathrm{P} / \mathrm{SS}$ \\
\hline 14.4 & 12.59 & 6.89 & -11 & 19.30 & SS & 28.4 & 16.97 & 3.45 & -11 & 1.99 & $\mathrm{P} / \mathrm{SS}$ \\
\hline
\end{tabular}


Table 2. Triaxial test statistics

\begin{tabular}{lrllll}
\hline Data & \multicolumn{2}{c}{ Strength } & Confining & Strain rate & Specimen \\
Set & Mean & Std dev. & pressure & & temp. \\
No. & & & & & \\
& $\mathrm{MPa}$ & $\mathrm{MPa}$ & $\mathrm{MPa}$ & $\times 10^{-3} \mathrm{~s}^{-1}$ & ${ }^{\circ} \mathrm{C}$ \\
\hline
\end{tabular}

\section{Labrador ice}

$\begin{array}{rrrrcr}1 & 4.43 & 1.00 & 0.00 & 1.45 & -1 \\ 2 & 10.29 & 0.68 & 1.38 & 3.93 & -1 \\ 3 & 10.17 & 0.95 & 3.45 & 4.34 & -1 \\ 4 & 10.74 & 1.07 & 6.89 & 4.84 & -1 \\ 5 & 8.67 & 0.60 & 13.79 & 5.13 & -1 \\ 6 & 12.27 & 0.95 & 1.38 & 3.76 & -6 \\ 7 & 13.22 & 0.85 & 6.89 & 4.73 & -6 \\ 8 & 7.82 & 1.63 & 0.00 & 1.63 & -11 \\ 9 & 10.75 & 0.84 & 1.38 & 77.50 & -11 \\ 10 & 14.64 & 0.89 & 1.38 & 3.46 & -11 \\ 11 & 3.50 & 0.21 & 1.38 & 0.0482 & -11 \\ 12 & 11.98 & 1.21 & 3.45 & 75.50 & -11 \\ 13 & 13.19 & 1.83 & 3.45 & 4.17 & -11 \\ 14 & 13.79 & 1.83 & 6.89 & 58.50 & -11 \\ 15 & 16.05 & 0.78 & 6.89 & 4.21 & -11 \\ 16 & 4.75 & 0.35 & 6.89 & 0.0596 & -11 \\ 17 & 14.97 & 1.34 & 13.79 & 32.00 & -11 \\ 18 & 16.01 & 0.61 & 13.79 & 5.67 & -11 \\ 19 & 18.42 & 1.26 & 1.38 & 3.99 & -16 \\ 20 & 19.71 & 2.33 & 6.89 & 5.57 & -16\end{array}$

\section{Greenland 1 ice}

$\begin{array}{rrrrrr}21 & 8.63 & 0.54 & 0.00 & 1.45 & -11 \\ 22 & 15.91 & 0.65 & 3.45 & 3.75 & -11\end{array}$

\section{Greenland 2 ice}

$\begin{array}{rrrrrr}23 & 7.28 & 0.53 & 0.00 & 1.54 & -11 \\ 24 & 16.96 & 0.13 & 3.45 & 2.56 & -11\end{array}$

\section{Greenland 3 ice}

$\begin{array}{rrrrrr}25 & 7.44 & 0.63 & 0.00 & 1.15 & -11 \\ 26 & 18.42 & 0.67 & 3.45 & 2.02 & -11\end{array}$

\section{Greenland 4 ice}

\begin{tabular}{rrrrrr}
27 & 11.09 & 1.00 & 0.00 & 1.54 & -11 \\
28 & 16.60 & 2.60 & 3.45 & 1.99 & -11 \\
\hline
\end{tabular}

the axis of the specimen. Brittle fracture was also exhibited in some specimens by a coalescence of smaller, but substantial, cracks that formed an apparent wide (several centimetres) shear fault, inclined at angles in the range of $2040^{\circ}$ to the axis of the sample. Similar shear faults have been observed before in polycrystalline freshwater ice (e.g. Rist and Murrell, 1994) and are the result of confining stresses at the ends of the samples, due to the end platens, which prevent axial cleavage. Brittle fracture by either axial cleavage or wide shear faulting is referred to below as the fracture mode. The second failure mode was ductile failure, designated as plastic (Fig. 3b). The sample was loaded to a maximum value and began to deform ductilely, primarily by microcracking, because confining pressure prevented large brittle fractures. The third failure mode was shear-slip (Fig. 3c), where the specimen initially fractured along a shear plane and then slipped along the plane. In theory, an angle of $45^{\circ}$ will yield the maximum shear force per unit along a plane passing through a cylinder experiencing uniaxial stress. This was verified, in practice, for a number of samples which failed in this manner but it was more common for the shear plane to be inclined at angles in the range of 30 $45^{\circ}$ to the sample axis. Finally, there was combined plastic and shear-slip failure (Fig. 3d), designated as plastic shear-slip.

Figure 4 shows the stress and strain records corresponding to the four tested specimens shown in Figure 3. Figure $4 \mathrm{a}$ illustrates the characteristics of fracture failure where the load rises in a fairly linear fashion to a peak value at which point the sample fails. The sample cannot support any significant load after the failure. All uniaxial tests resulted in the fracture mode of failure.

Figure $4 \mathrm{~b}$ shows characteristics of plastic failure. Load rises fairly linearly at first and then the slope decreases as the plastic failure initiates. A rounded maximum peak value is attained, after which the load decreases smoothly to a fairly constant value at the higher strains. In general, the difference between the height of the peak and the steady load at the higher strains decreased as strain rate decreased, temperature increased and confining pressure increased. The resulting deformation was evident as radial expansion of the sample, sometimes uniform and at other times more pronounced in certain areas, e.g. Figure $4 \mathrm{~b}$ shows more expansion at the bottom of the specimen than at the top. This ductile deformation of ice, apparently caused by extensive non-interacting microcracking, has been observed by others (e.g. Jones, 1982; Rist and Murrell, 1994). During tests where plastic failure occurred, in the present study, microcracking could be heard.

An example of shear-slip failure is illustrated in Figure $4 \mathrm{c}$. In this test, the load rose linearly to a peak value at which point an abrupt shear fracture and slip occurred, followed by somewhat erratic small-amplitude variations. The latter indicated fairly continuous slippage along the shear plane with small-amplitude variations, possibly due to slight stick-slip behaviour, in shear stress during the sliding. In general, for tests conducted at $-11^{\circ} \mathrm{C}, 5 \times 10^{-2}$ $\mathrm{s}^{-1}$ strain rate and at 6.89 and $13.79 \mathrm{MPa}$, the load following the initial slip was significantly lower than the initial peak if the shear plane did not intersect one of the end platens. In cases where the shear plane did intersect with a platen, multiple shear planes developed, parallel and/or orthogonal to each other, and the load after the first slip could peak to values of the same magnitude or even higher than the first peak. For the shear-slip tests conducted at lower confining pressures (other parameters the same), the load record was similar to Figure 4c, but much smoother after the initial fracture. Following the peak stress, the load dropped sharply and then followed a fairly smooth curve that appeared to approach asymptotically some low constant value. Smooth and continuous slipping was also reflected in the strain data. In the figure, the slight anomalous negative readings, appearing at 


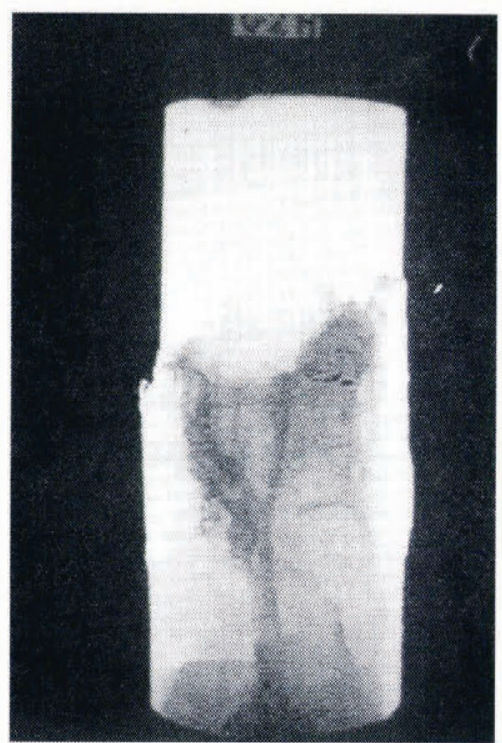

a

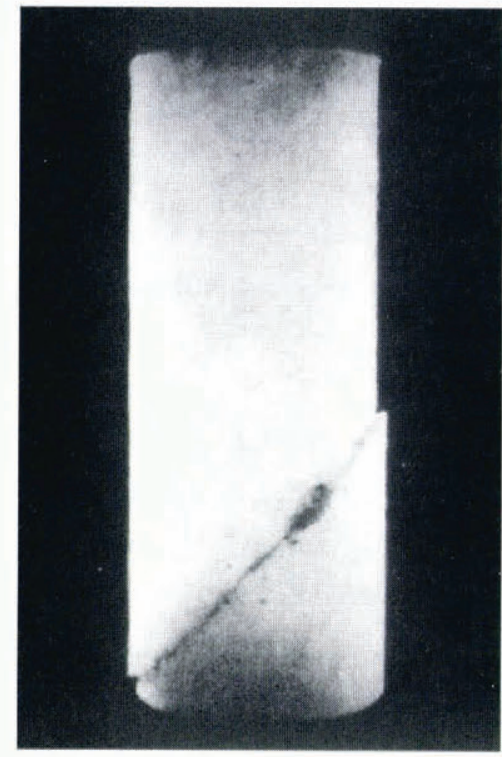

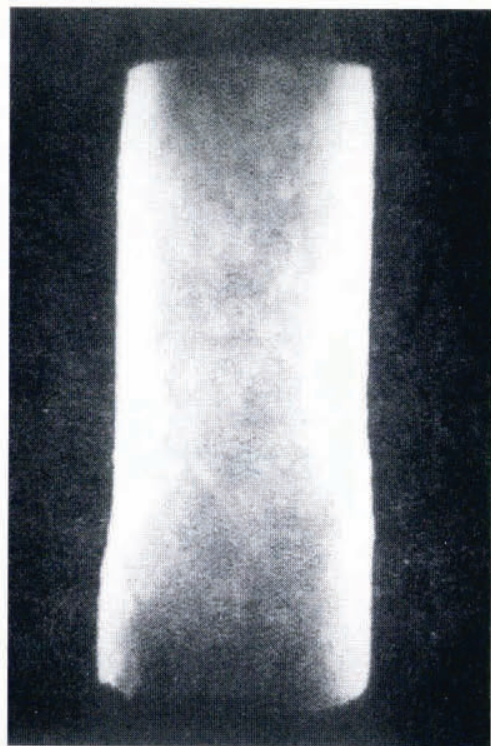

b

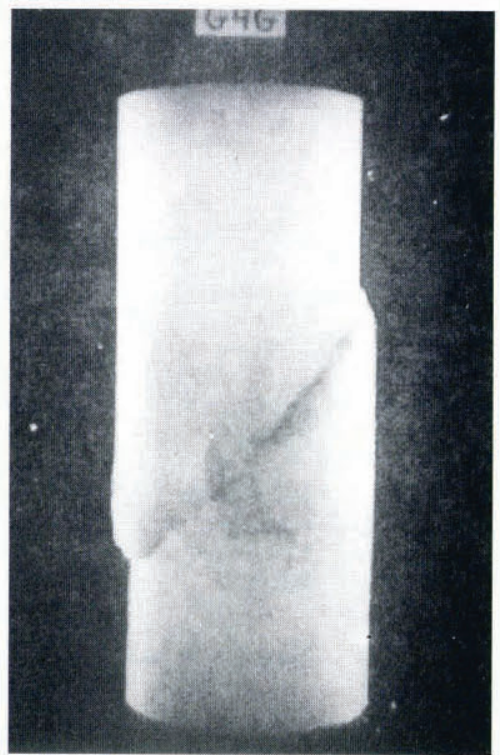

c

Fig. 3. Examples of each type of ice failure. (a) Fracture. Test No. 23.4, see parameters in Table 1; (b) Plastic. Test No. 6.2; (c) Shear-slip. Test No. 14.5; (d) Plastic/shear-slip. Test No. 28.4.

about $0.27 \mathrm{~s}$ in the strain record, arise from oscillations of the extensometer due to the initial bump of the piston when it makes contact with the sample. Shear slip tests, at $-1^{\circ} \mathrm{C}$, confining pressure of $1.38 \mathrm{MPa}$ and at a strain rate of $5 \times 10^{-3} \mathrm{~s}^{-1}$, showed no sharp initial peak at all and the load and strain records looked very similar to that of plastic failure, as in Figure 4b. Shear-slip type failure has been observed in granular fresh-water ice at temperatures below $-78^{\circ} \mathrm{C}$ (Durham and others, 1983), in sea ice at $-10^{\circ} \mathrm{C}$ (Sammonds and others, 1989) and granular fresh-water ice at $-40^{\circ} \mathrm{C}$ (Rist and Murrell, 1994). In only one instance did we observe shear-slip accompanied by large secondary axial cracks, similar to that of Rist and Murrell (1994). This may have resulted from a leak in the rubber membranes surrounding the specimen; however, at the time, the discarded membranes were not carefully inspected to confirm this, and the confining fluid would have evaporated from the specimen. The load record for this test was also anomalous in that the value towards the usually stable region near the end of the test was only about $50 \%$ of that of other tests conducted with the same test parameters.

Figure 4d illustrates plastic/shear-slip failure. Load increased linearly to a peak value at which point the sample fractured and slipped along a shear plane. Load immediately began to accumulate to another peak value where an abrupt shear slip along the plane occurred again. This pattern repeated itself fairly regularly until in the latter half of the test curvature became evident in the load rises, indicating plastic failure within the bulk specimen and possibly continuous slippage along the shear plane. Successive load peaks were often as high and sometimes even higher (Fig. 4d) than previous ones in the same test! The maximum peak could occur anywhere in the record. The multiple-slip phenomenon, and remarkable recovery of strength with successive slips, has been observed by others (e.g. Durham and others, 1983). Though not classified as plastic/shear-slip, there were a 


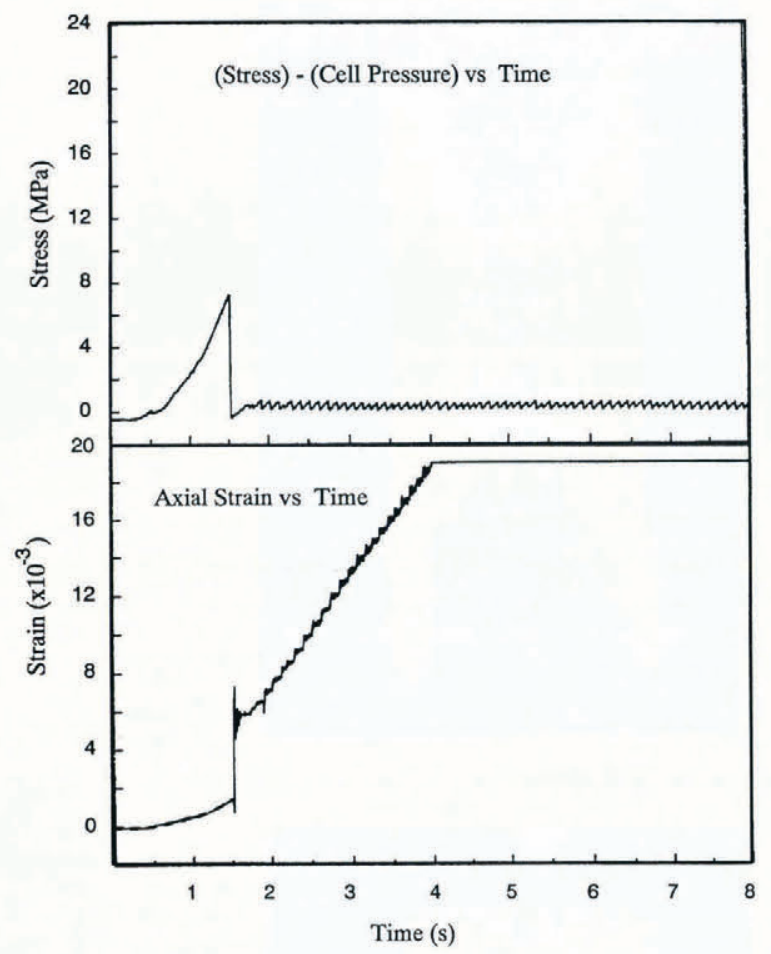

a

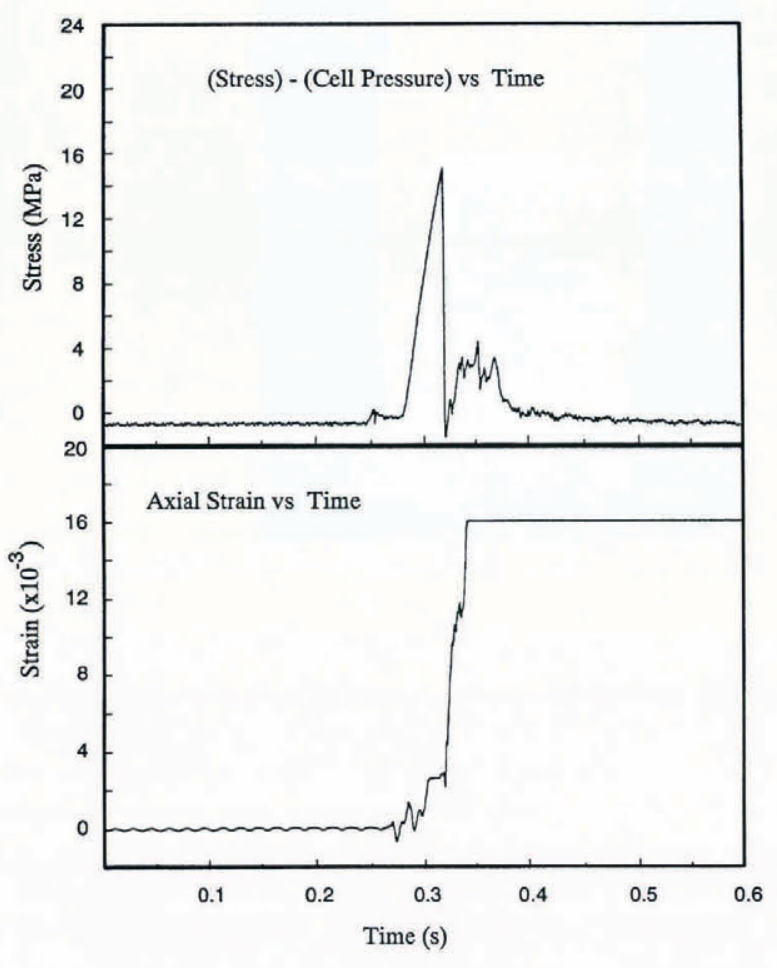

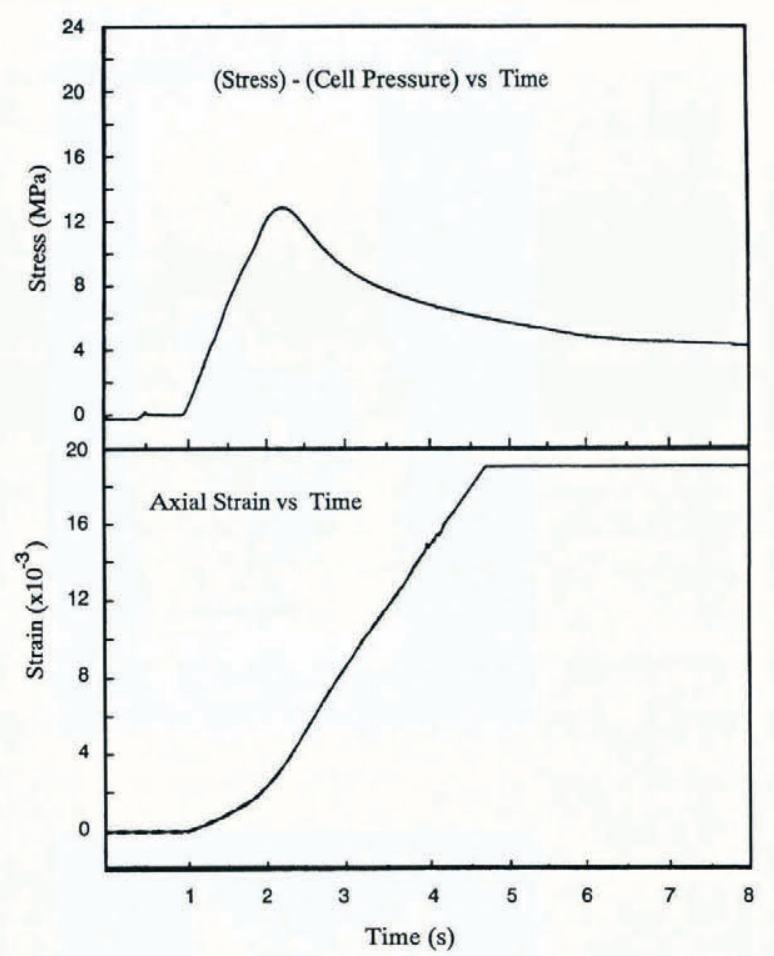

b

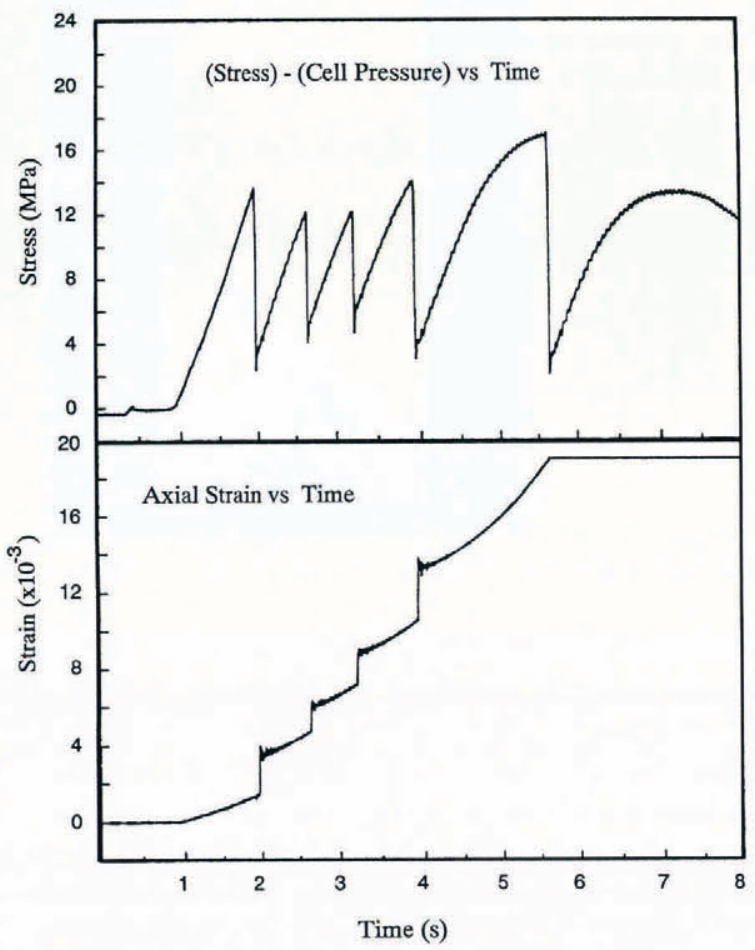

d

Fig. 4. Plots of stress minus cell pressure us time and axial strain vs time for the triaxial tests shown in Figure 3. (a) Fracture. Test No. 23.4, see parameters in Table 1; (b) Plastic. Test No. 6.2; (c) Shear-slip. Test No. 14.5; (d) Plastic/shear-slip. Test No. 28.4. Strain records are not meaningful after the flat plateau is reached. The slight anomalous negative readings, appearing at about $0.27 \mathrm{~s}$ in the strain record of Figure $4 c$, arise from oscillations of the extensometer due. to the initial bump of the piston when it makes contact with the sample.

couple of plastic tests where the load curve was typical for plastic failure but the samples exhibited a rather thick (approximately $1 \mathrm{~cm}$ ) shear plane. The ice in the plane was highly deformed, whereas the rest of the specimen was relatively undeformed. One of these experiments belonged to the $-11^{\circ} \mathrm{C}, 6.89 \mathrm{MPa}, 5 \times 10^{-5} \mathrm{~s}^{-1}$ test series and the other to the $-11^{\circ} \mathrm{C}, 3.45 \mathrm{MPa}, 5 \times 10^{-3} \mathrm{~s}^{-1}$ test series. For each shear-slip that occurred during plastic/ shear-slip tests there was a loud audible bang.

Figure 5 shows the types of failures that resulted throughout the ranges of confining pressure and strain rate for tests at $-11^{\circ} \mathrm{C}$. All uniaxial experiments failed in 


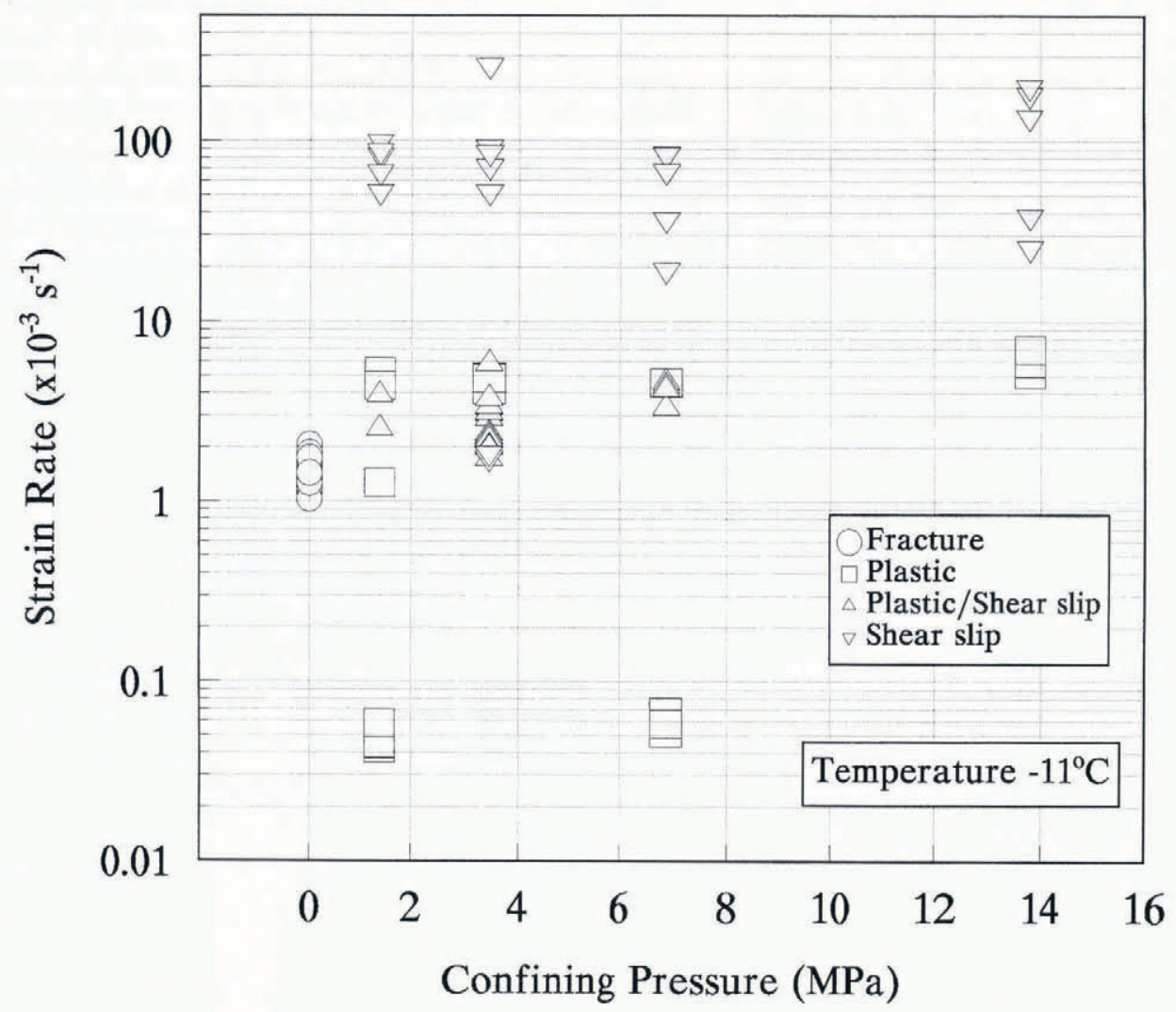

Fig. 5. Plot of all experiments performed at $-11^{\circ} \mathrm{C}$, indicating the strain rate, confining pressure and the type of failure for each test.

fracture. Plastic failure was evident in the $5 \times 10^{-3} \mathrm{~s}^{-1}$ strain-rate region at all confining pressures, except $0.0 \mathrm{MPa}$, and at the two confining pressures where tests were conducted at $5 \times 10^{-5} \mathrm{~s}^{-1}$. Plastic/shear slip occurred in the $5 \times 10^{-3} \mathrm{~s}^{-1}$ strain-rate range at confining pressures in the range of $1.38-6.89 \mathrm{MPa}$. Shear slip occurred in the $5 \times 10^{2} \mathrm{~s}^{-1}$ strain-rate region at all confining pressures, except $0.0 \mathrm{MPa}$, and in the $5 \times 10^{-3}$ $\mathrm{s}^{-1}$ strain-rate region at a confining pressure of $3.45 \mathrm{MPa}$. Plastic, shear-slip and plastic/shear-slip were evident at the confining pressure of $3.45 \mathrm{MPa}$ in the $5 \times 10^{-3} \mathrm{~s}^{-1}$ strain-rate range.

\section{General features of the data}

The trends in the data can be stated as follows. There was a consistent increase in the strength of the ice with decreasing temperature. For example, Labrador ice tested at a cell pressure of $1.38 \mathrm{MPa}$ and strain rate of $5 \times 10^{3}$ $\mathrm{s}^{-1}$ experienced a $79 \%$ increase in strength over the temperature range $-1^{\circ}$ to $-16^{\circ} \mathrm{C}$ (Figs 6 and 7 ). There was also an increase in strength with confining pressure for ice at the lower temperatures (Figs 6, 7 and 8). Others (e.g. Jones, 1982; Murrell and others, 1991) have observed an increase in strength of polycrystalline ice with confining pressure in the pressure range here. Labrador ice tested at $-11^{\circ} \mathrm{C}$ and a strain rate of $5 \times 10^{-3} \mathrm{~s}^{-1}$ experience a $105 \%$ increase in strength as confining pressure increased from 0 to $13.79 \mathrm{MPa}$. However, for warmer ice $\left(-1^{\circ} \mathrm{C}\right)$, a noticeable weakening occurred at the higher confining pressures (Fig. 6). This was attributable to the freezing-point depression which

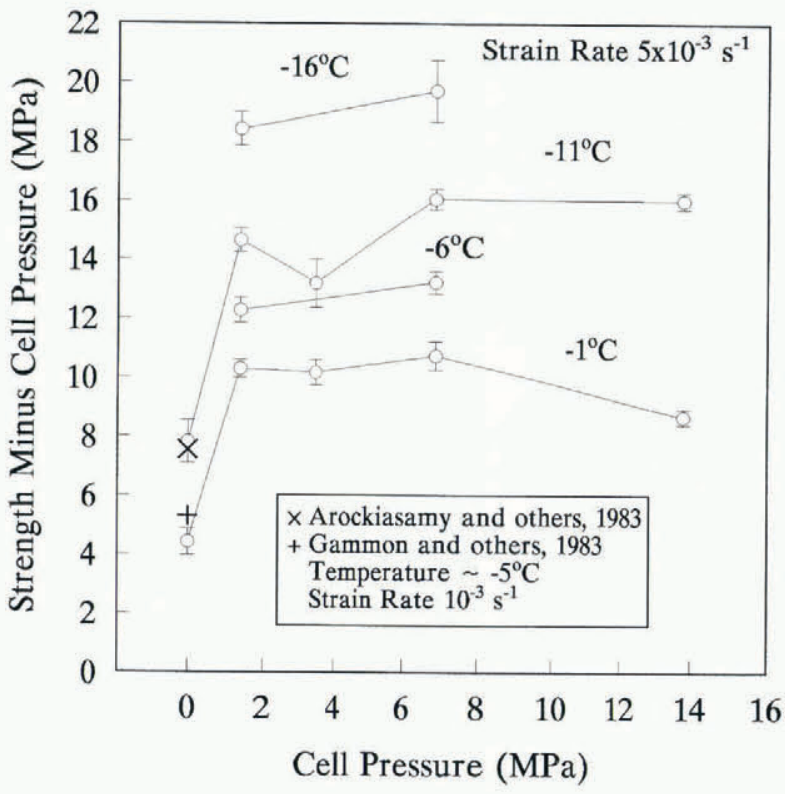

Fig. 6. Four plots of strength minus cell pressure vs cell pressure for triaxial tests on Labrador ice at a strain rate of $5 \times 10^{-3} \mathrm{~s}^{-1}$ and at temperalures ranging from $-1^{\circ}$ to $16^{\circ} \mathrm{C}$. Each point represents the mean of five tests and the corresponding error bar represents the standard error in the mean. Standard error is equal to the standard deviation divided by the square root of the sample size. Data from Arockiasamy and others (1983), and Gammon and others (1983), have been plotted for comparison. 


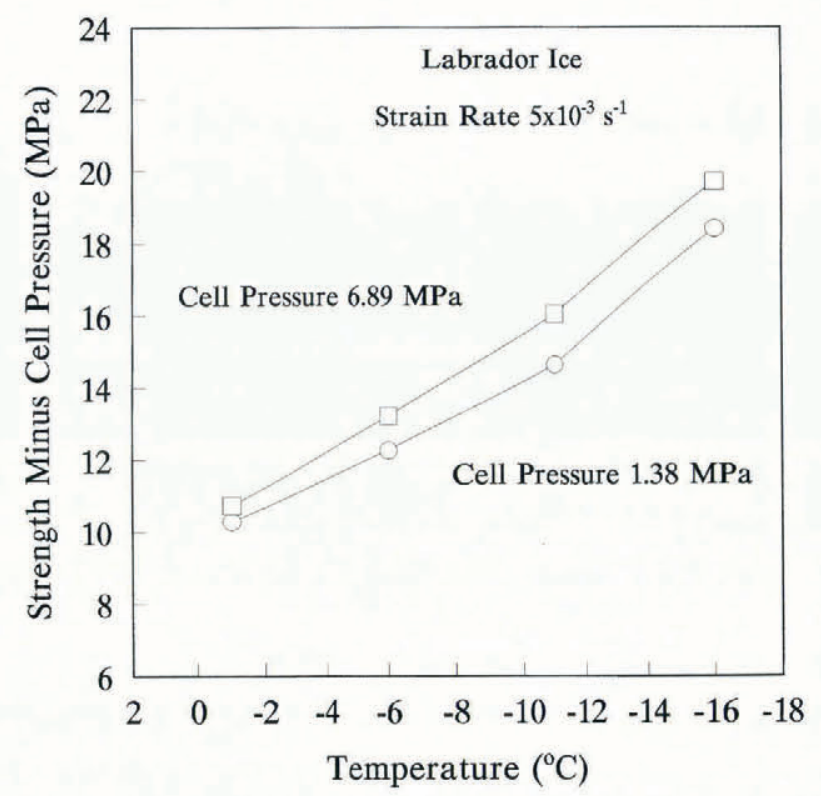

Fig. 7. Plots of strength minus cell pressure vs temperature at cell pressures of 1.38 and $6.89 \mathrm{MPa}$ for triaxial tests on Labrador ice at a strain rate of $5 \times 10^{-3} \mathrm{~s}^{-1}$.

results from confining pressure and which would have a non-negligible effect only on ice near the freezing point (i.e. $-1^{\circ} \mathrm{C}$ ). The decrease in strength with higher confining pressure at $-1^{\circ} \mathrm{C}$ and overall shape of the data trend at that temperature (Fig. 6) are suggestive of the teardrop-shaped failure envelope proposed by Nadreau and Michel (1986).

The increase in strength with increasing confining pressure at the low confinement end, and the relative independence of strength on increasing confinement at the higher confining pressures, are distinctive features of the data. They suggest that a frictional sliding mechan-

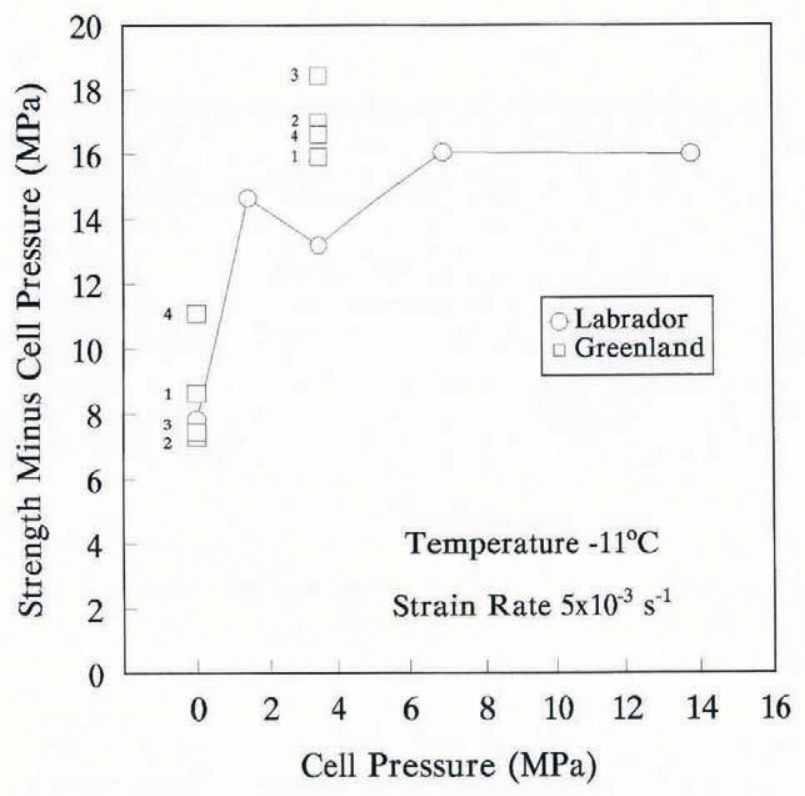

Fig. 8. Plot of strength minus cell pressure for triaxial tests on Labrador ice at a temperature of $-11^{\circ} \mathrm{C}$ and a strain rate of $5 \times 10^{-3} s^{-1}$. Also shown are the strength values for the four types of Greenland ice at two confining pressures. ism, for example, the one proposed by Schulson and others (1991), controls the behaviour at low confinement and that plastic processes (discussed by Duval and others (1983)) govern the behaviour at high confinement.

The strength of the ice was found to depend strongly on strain rate. For Labrador specimens at $-11^{\circ} \mathrm{C}$, ice strength was predictably lowest for tests at $0.05 \times 10^{-3} \mathrm{~s}^{-1}$ (Fig. 9). On the other hand, ice tested at $50 \times 10^{-3} \mathrm{~s}^{-1}$, though greater in strength than the $0.05 \times 10^{-3} \mathrm{~s}{ }^{1}$ tests, was lower in strength than ice tests at $5 \times 10^{-3} \mathrm{~s}^{-1}$. Such behaviour has not been observed in other triaxial experiments on fresh-water ice (e.g. Jones, 1982; Murrell and others, 1991), suggesting a distinct difference in the behaviour of glacial ice from ice grown in the laboratory. The behaviour in the present study can be explained by viewing the chart records for the tests. They indicate that at $5 \times 10^{-3} \mathrm{~s}^{-1}$ brittle behaviour (i.e. formation of shearslip planes) generally occurred at higher stress than in tests at $50 \times 10^{-3} \mathrm{~s}^{-1}$. Hence, the ice tested at $5 \times 10^{-3} \mathrm{~s}^{-1}$ usually approached or reached its highest possible strength and then yielded ductilely while the higher strain rates precipitated brittle fracture in the specimens before the test got very far into the ductile regime. In uniaxial compressive tests, in the same range of strain rate, Cole (1987) and Schulson (1990) observed a decrease in strength as strain rate increased. Schulson (1990) discussed this in terms of competition between tensile stress build-up and stress relaxation at wing-crack tips. The former dominates at the higher strain rate so crack extension is facilitated. At lower strain rates, stress relaxation at the crack tip dominates and crack extension is suppressed.

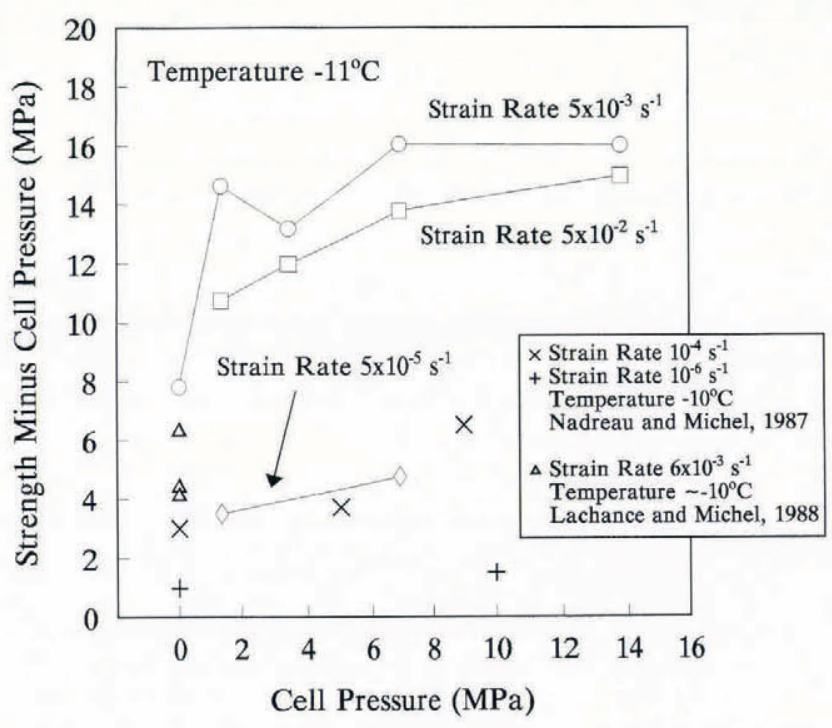

Fig. 9. Three plots of strength minus cell pressure vs cell pressure for triaxial tests on Labrador ice at a temperature of $-11^{\circ} \mathrm{C}$ and strain rates ranging from $5 \times 10^{-5}$ to $5 \times 10^{2} s^{-1}$. Data from Nadreau and Michel (1987) and Lachance and Michel (1988) have been plotted for comparison.

From Figure 5, it appears that the strain rate at which the transition from ductile to brittle behaviour occurs increases with confining pressure. This is consistent with 
the behaviour one might expect from the wing-crack model of Schulson (1990), since a confining stress would decrease the sliding velocity of the faces of the primary crack. This could lower the rate of tensile stress build-up in the region of wing-crack tips to levels below that required for crack extension. The samples tested in this program, however, were not inspected for the presence of wing cracks.

Whether the apparent drop in strength of the Labrador ice at a confining pressure of $3.45 \mathrm{MPa}$ (Fig. 6 ), pronounced at $-11^{\circ} \mathrm{C}$ and slight at $-1{ }^{\circ} \mathrm{C}$, is a real phenomenon or an artifact of the selection of ice samples is not certain. More experiments would be required to resolve this.

\section{Frictional behaviour and activation energy}

The frictional behaviour during shear slip events of ice that failed in the plastic/shear-slip mode was very similar to that reported by Rist and Murrell (1994). A sampling of shear and normal stresses, corresponding to stick slip maxima from several tests spanning the full temperature range of the data, was found to agree with the frictional relationship reported by Rist and Murrell (1994), i.e. $\tau=1.5 \times \sigma^{0.65}$, where $\tau$ and $\sigma$ are the shear stress and normal stress on the shear plane.

Because a significant amount of energy was dissipated in the shear plane during a slip event in a plastic/shearslip test, it is likely that melting, resulting from friction and possibly pressure melting on asperities, occurred. The energy dissipation during a typical shear-slip event, in a test such as that illustrated in Figure 4d, can be calculated from estimates of force, obtained from the stress records, and displacement, taken from the strain records and photographs of tested samples. The extent of slippage per event is approximately $0.6 \mathrm{~mm}$. The shear stress during the slippage, assuming the shear plane is at $45^{\circ}$ and taking the differential stress in the sample during the slip as the stress midway between the peak and minimum stress during the slip, is typically $4 \mathrm{MPa}$. Hence, the shear force multiplied by the distance of the slippage yields the energy dissipated, approximately $25 \mathrm{~J}$. This amount of energy could create a layer of liquid at the shear plane that was approximately $7 \mu \mathrm{m}$ thick. At the lower temperatures, refreezing of melt after a shear slip would enable the ice sample to regain its original strength. The presence of lubricating melt could also explain why the shear slippage for the tests conducted at the highest strain rates (Fig. 4c) was not of a pronounced stick-slip nature. In that case, the nominal actuator speed and stiffness of the ice/apparatus system did not allow low enough relative speeds between the two faces of the shear plane, or long enough time durations if the slippage momentarily stopped, for refreezing and healing to occur. Similarly, for the shear-slip tests conducted at $-1^{\circ} \mathrm{C}$, the ice was not sufficiently cold to cause rapid enough refreezing of melt to bond the surfaces. It is interesting that liquid-layer thicknesses, of similar magnitude $(<20 \mu \mathrm{m})$, have been detected at the ice/steel interface when single crystals of fresh-water ice have been crushed against an instrumented stainless steel platen at $-10^{\circ} \mathrm{C}$ (Gagnon, 1994).

In this test program, data were not obtained at a broad enough range of temperature and strain rate to permit calculation of an independent activation energy. However, for the purpose of comparison, a semiindependent value was determined. The familiar powerlaw creep equation for ice is

$$
\dot{\varepsilon}=A \sigma^{n} \exp -\frac{Q}{R T}
$$

where $n$ and $A$ are material constants, $\sigma$ is the differential stress, $Q$ is the activation energy, $R$ is the molar gas constant and $T$ is the absolute temperature. The steadystate stress data from the tests that failed in the plastic mode, corresponding to $6.89 \mathrm{MPa}$ throughout the full temperature range, were least-squares fitted to Equation (1) assuming a value of $n=4.2$ from Rist and Murrell (1994). The fit was excellent $\left(R^{2}>0.99\right)$ and the activation energy obtained was $Q=101 \mathrm{~kJ} \mathrm{~mol}^{-1}$. The value is high compared to that of others e.g. Rist and Murrell (1994): $Q=69 \mathrm{~kJ} \mathrm{~mol}^{-1}$; Budd and Jacka (1989): $Q=72 \mathrm{~kJ} \mathrm{~mol}^{-1}$; Sinha (1978): $Q=67 \mathrm{~kJ} \mathrm{~mol}^{-1}$ ) corresponding to temperatures at or below $-10^{\circ} \mathrm{C}$. A high value is to be expected, however, since half the data points used for the present calculation correspond to temperatures above $-10^{\circ} \mathrm{C}$. Others have found high values for the activation energy at temperatures above $-10^{\circ} \mathrm{C}$ (e.g. Barnes and others, 1971) and this has been attributed to the presence of liquid at grain boundaries. The same effect apparently operates at lower temperatures when the confining pressure is sufficiently high. A value close to ours was found by Durham and others (1983) for triaxial tests on ice performed over the temperature range of $-15^{\circ}$ to $-30^{\circ} \mathrm{C}$, at a confining pressure of $50 \mathrm{MPa}$. The high activation energy $\left(n=4\right.$ and $\left.Q=91 \mathrm{~kJ} \mathrm{~mol}^{-1}\right)$ was attributed to grain-boundary softening associated with the presence of liquid at grain boundaries. Apart from the high temperature effect on our calculation of activation energy, we speculate that another grain-boundary effect, namely, the reduction of crack-initiating stresses at grain boundaries due to intragranular air-bubble inclusions, discussed below may have influenced our value.

\section{Strength characteristics of the ice types}

At $-11^{\circ} \mathrm{C}$ and a strain rate of $5 \times 10^{-3} \mathrm{~s}^{-1}$, Greenland ice at a confining pressure of $3.45 \mathrm{MPa}$ was invariably stronger than Labrador ice (Fig. 8) under corresponding conditions. At zero confining pressure, ice from sources G3 and G2 was approximately $6 \%$ lower in strength than Labrador ice while ice from sources G1 and G4 was distinctly higher in strength, $10 \%$ and $42 \%$, respectively (Fig. 10).

For Greenland ice, which was relatively free of cracks, there appeared to be an inverse correlation between uniaxial and triaxial strength. Figure 8 indicates that ice which was weak at zero confining pressure benefited the most in strength when confining pressure was applied. This pattern was broken for Labrador ice possibly because of its relatively high density of cracks. The presence and distribution of bubbles, discussed below, may be responsible for the phenomenon in Greenland ice.

In general, there was rough agreement in trends and absolute values between the present results and those from other uniaxial and triaxial experiments on iceberg 


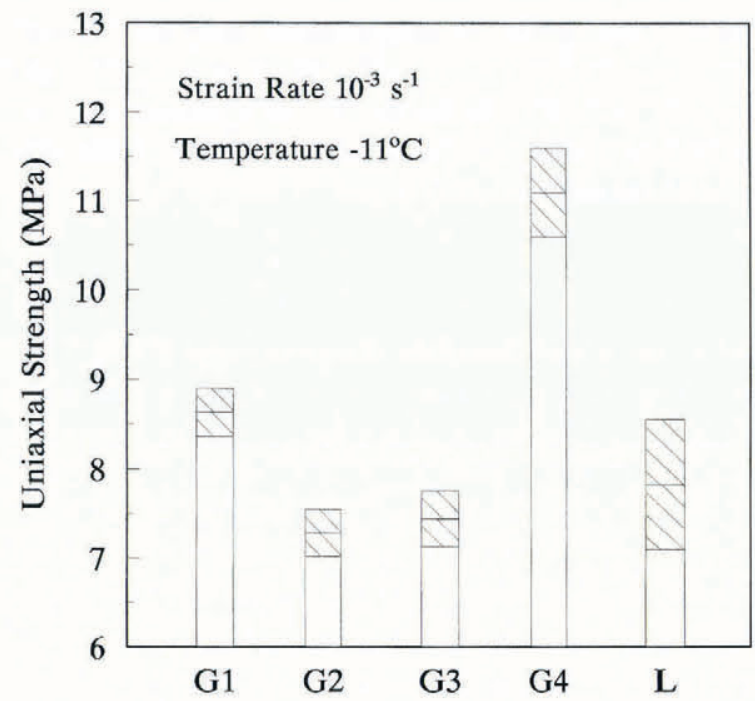

Fig. 10. Chart of uniaxial strength for Greenland and Labrador ice tested at a temperature of $-11^{\circ} \mathrm{C}$ and a strain rate of $10^{-3} \mathrm{~s}^{-1}$. On each vertical bar the dark horizontal line through the hatched area represents the mean value of a set of strength data and the corresponding hatched areas represent the standard error in the mean.

ice. Extrapolating our results to account for the differences in test conditions, indicated rough agreement with the uniaxial test data of Arockiasamy and others (1983), Gammon and others (1983) and Nadreau and Michel (1987) (Figs 6 and 9). Similarly, the data of Nadreau and Michel (1987), for tests at confined pressures, were roughly compatible with our data (Fig. 9 ). The mean uniaxial compressive strengths of ice from three different icebergs, determined by Lachance and Michel (1988), were perhaps the exception, in that two of the values were quite low compared to our value (Fig. 9). Curiously, their value (4.4 MPa) for ice obtained from the same Labrador iceberg referred to here was considerably lower than our value $(7.82 \mathrm{MPa})$. We have no explanation for this.

The unconfined compressive strength of the iceberg and glacier ice studied here is greater than columnar pond ice (Gammon and others, 1983) and fresh-water granular ice grown in the laboratory (Schulson and Cannon, 1984; Cole, 1987) with grains of comparable size. Granular ice with small grains is stronger in unconfined compression than the iceberg and glacier ice tested here, except perhaps the Greenland 4 ice. This is the result of the inverse dependence of unconfined compressive strength on grain-size (Cole, 1987), since iceberg ice is generally composed of large grains (Gagnon and Gammon, 1995).

\section{Influence of air bubbles}

Variations in porosity, grain-size and shape, crack density and orientation, and preferred crystallographic $c$-axis orientation all play some role in determining the strength of ice. However, no unambiguous correlations of strength with these parameters were identifiable from the data. Analysis of the bubble population, on the other hand, demonstrated that the dominant factor differentiating the uniaxial strengths of the four Greenland ice types is the bubble density, that is, the number of bubbles per unit volume. The detailed ice characterization data (Tables 3 and 4) of Gagnon and Gammon (1995), which included air-bubble dimensions and fractional porosity measure-

Table 3. Ice-characterization data (Gagnon and Gammon, 1995)

\begin{tabular}{|c|c|c|c|c|c|c|c|c|c|}
\hline $\begin{array}{l}\text { Ice type and } \\
\text { orientation }\end{array}$ & $\begin{array}{c}\text { Mean grain } \\
\text { diameter } \\
\mathrm{mm}\end{array}$ & $\begin{array}{l}\text { Std dev. } \\
\mathrm{mm}\end{array}$ & $\begin{array}{l}\text { Maximum } \\
\text { observed grain } \\
\text { diameter } \\
\mathrm{mm}\end{array}$ & $\begin{array}{c}\text { Mean long and } \\
\text { short bubble } \\
\text { diameter } \\
\text { mm }\end{array}$ & $\begin{array}{l}\text { Std dev. } \\
\mathrm{mm}\end{array}$ & $\begin{array}{c}\text { Maximum } \\
\text { observed bubble } \\
\text { diameter } \\
\mathrm{mm}\end{array}$ & $\begin{array}{l}\text { Bubble density } \\
\qquad \# \mathrm{~mm}^{3}\end{array}$ & $\begin{array}{l}\text { Preferred c-axis } \\
\text { orientation }^{*}\end{array}$ & $\begin{array}{c}\text { Grain } \\
\text { elongation }\end{array}$ \\
\hline $\begin{array}{l}\text { G1 } \\
\text { G1P } \\
\text { G1PP }\end{array}$ & $\begin{array}{r}9.16 \\
3.96 \\
12.95\end{array}$ & $\begin{array}{l}5.73 \\
1.77 \\
5.17\end{array}$ & $\begin{array}{l}31.63 \\
10.75 \\
25.64\end{array}$ & $\begin{array}{l}0.38 \\
0.33\end{array}$ & 0.28 & 1.20 & 1.30 & Moderate & Slight \\
\hline $\begin{array}{l}\text { G2 } \\
\text { G2P } \\
\text { G2PP }\end{array}$ & $\begin{array}{l}16.55 \\
15.84 \\
24.44\end{array}$ & $\begin{array}{l}6.07 \\
5.30 \\
6.06\end{array}$ & $\begin{array}{l}37.94 \\
35.21 \\
35.32\end{array}$ & $\begin{array}{l}0.34 \\
0.27\end{array}$ & 0.23 & 1.20 & 0.49 & Moderate & Slight \\
\hline $\begin{array}{l}\text { G3 } \\
\text { G3P } \\
\text { G3PP }\end{array}$ & $\begin{array}{l}18.91 \\
23.40 \\
23.30\end{array}$ & $\begin{array}{r}8.43 \\
8.62 \\
10.38\end{array}$ & $\begin{array}{l}40.48 \\
61.25 \\
57.55\end{array}$ & $\begin{array}{l}0.55 \\
0.39\end{array}$ & 0.39 & 1.46 & 0.40 & Moderate & Slight \\
\hline $\begin{array}{l}\text { G4 } \\
\text { G4P } \\
\text { G4PP }\end{array}$ & $\begin{array}{l}16.43 \\
17.92 \\
18.06\end{array}$ & $\begin{array}{l}7.73 \\
9.59 \\
9.86\end{array}$ & $\begin{array}{l}42.97 \\
49.52 \\
51.30\end{array}$ & $\begin{array}{l}0.30 \\
0.23\end{array}$ & 0.14 & 0.69 & 3.02 & Moderate & Moderate \\
\hline $\begin{array}{l}\text { L04 } \\
\text { L04P } \\
\text { L04PP }\end{array}$ & $\begin{array}{l}9.69 \\
8.71 \\
6.03\end{array}$ & $\begin{array}{l}4.53 \\
3.26 \\
2.21\end{array}$ & $\begin{array}{l}22.83 \\
20.92 \\
12.97\end{array}$ & $\begin{array}{l}0.32 \\
0.27\end{array}$ & 0.21 & 1.09 & 2.66 & Strong & Moderate \\
\hline
\end{tabular}

\footnotetext{
* Moderate preferred $c$-axis orientation implies $20 \%$ of grains align simultaneously to extinction. Strong preferred $c$-axis orientation implies greater
} than $35 \%$ of grains align simultaneously to extinction.

Note: Three different mutually orthogonal orientations are distinguished by the absence or presence of a single or double letter $\mathrm{P}$ (for perpendicular) which appears after the ice-source ID number in the lefthand column. 
Table 4. Fractional porosity (Gagnon and Gammon, 1995)

\begin{tabular}{lcc}
\hline Sample type & $\begin{array}{c}\text { Number of } \\
\text { measurements }\end{array}$ & $\begin{array}{c}\text { Fractional porosity } \\
\%\end{array}$ \\
\hline G1 & 10 & $3.0 \pm 0.35$ \\
G2 & 10 & $0.7 \pm 0.20$ \\
G3 & 10 & $2.0 \pm 0.26$ \\
G4 & 10 & $2.8 \pm 0.23$ \\
L04 & 10 & $3.5 \pm 0.38$ \\
\hline
\end{tabular}

ments for the Greenland ice types, were used for the analysis. The bubble density was determined from the expression

$$
\text { Bubble density }\left(\# \mathrm{~mm}^{-3}\right)=\nu \times 1 \mathrm{~mm}^{3} / V_{\text {bubble }}
$$

where $\nu$ is the fractional porosity of the ice and $V_{\text {bubble }}$ is the mean bubble volume of the ice, given by

$$
V_{\text {bubble }}=\frac{4}{3} \pi(S / 2)^{3}+(L-S) \pi(S / 2)^{2}
$$

where $L$ and $S$ are the mean long and mean short diameters of the bubbles.

Figure 11 shows the uniaxial strength vs bubble density for the ice from the four different Greenland sources at $-11^{\circ} \mathrm{C}$ and strain rate of $5 \times 10^{-3} \mathrm{~s}^{-1}$. The uniaxial strength and bubble density are distinctly related. The uniaxial strength increases by approximately $49 \%$ over the range of bubble density 0.5

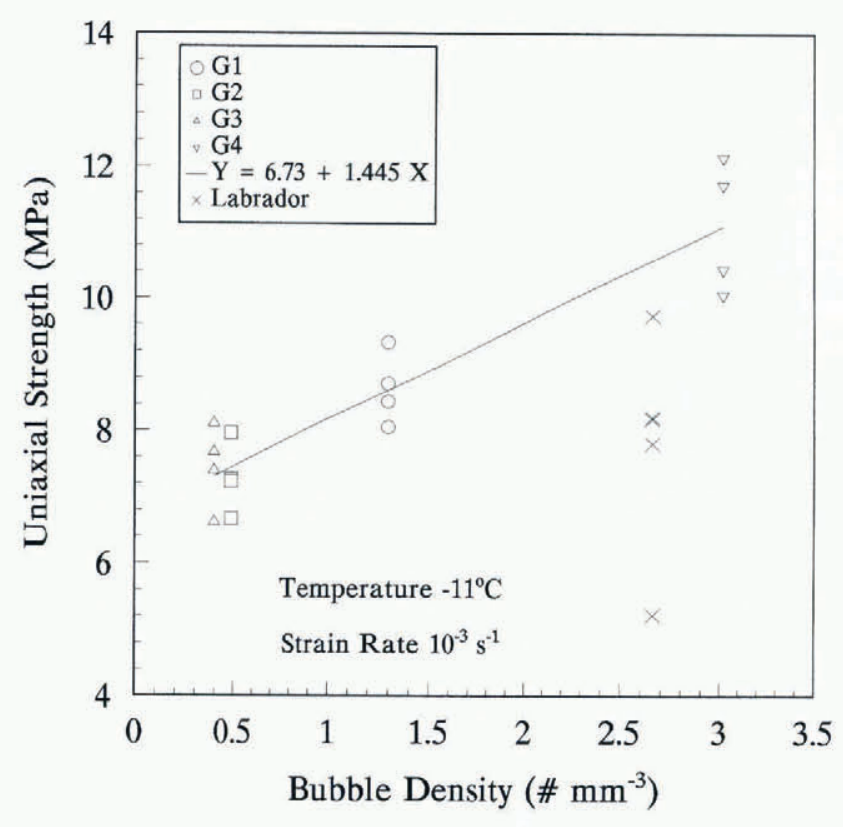

Fig. 11. Uniaxial strength vs bubble density for Greenland ice tested at a temperature of $-11^{\circ} \mathrm{C}$ and a strain rate of $10^{-3} s^{-1}$. The line through the data represents the best fit. Data from uniaxial strength tests on Labrador ice have been included for comparison. The actual bubble density for the Labrador ice data is not known.
$3 \mathrm{~mm}^{-3}$. Bubble characteristics for the particular Labrador ice used in uniaxial compression tests are not known. However, for comparison, the data have been placed on the graph using the bubble density for Labrador ice from another location at the quarry site on the Labrador iceberg (Gagnon and Gammon, 1995). The relatively small degree of scatter in the data for the Greenland ice results from the fact that the four samples tested for each type came from a single block of ice. The Labrador samples, on the other hand, came from four different blocks of ice that were quarried from non-adjacent sites, separated by several metres.

To explain the apparent dependence of flexural strength of glacial ice on bubble density, Gagnon and Gammon (1995) speculated that, in glacial ice, grains may be "softened" by the presence of internal air-bubble voids, that is, able to accommodate more strain for a given stress than grains without bubbles. This would reduce the intergranular stress concentrations that lead to crack initiation at grain boundaries. Hence, the more bubbles in the ice, up to a certain degree at least, the greater the flexural strength is. The present data for Greenland ice indicate that the same strengthening effect holds for the uniaxial strength of glacial ice. Granular ice, such as that grown in the laboratory, that has not experienced significant grain-boundary migration has air bubbles primarily located at the grain boundaries. There is evidence (e.g. Toope and others, 1991; Ebinuma and Maeno, 1992) that the presence of bubbles at grain boundaries in laboratory ice weakens it. The flexural strength of sea ice also decreases as the porosity, i.e. amount of brine and air inclusions at grain boundaries, increases (Timco and O'Brien, 1994). Hence, the strengthening effect of intragranular bubbles and weakening effect of intergranular bubbles may be the dominant mechanisms that explain why the uniaxial compressive strength of iceberg and glacial ice is generally greater than laboratory-grown granular ice of similar grain-size. Though the relevance to the discussion above is unclear, we note the possibility that crack propagation in ice may be inhibited by diffusion of stress at crack tips that intersect bubbles.

The discussion above suggests that ice from deep within glaciers and ice shelves would have a higher uniaxial strength than ice from shallower depths, since more recrystallization and grain-boundary migration would have occurred as a result of higher stresses and longer exposure to the stresses. Consequently, air bubbles would end up inside grains rather than at the grain boundaries, where they would have initially been in the early stages of ice formation from snow. This conclusion is supported by the uniaxial compressive-strength data from ice samples taken from a core through the entire thickness of Hobson's Choice Ice Island (Poplin and Ralston, 1992). Under the same test conditions of temperature and strain rate, ice from the bottom region of the core was stronger than ice from the top region. The authors could not account for this in terms of temperature, crystal structure or density of the ice. However, information about the physical characteristics and number of bubbles and their locations would be required to establish conclusively a relationship between bubbles and strength for ice from Hobson's Choice Ice Island. 


\section{SUMMARY AND CONGLUSIONS}

A comprehensive series of triaxial tests has been performed at various temperatures and strain rates on ice from four icebergs and one glacier. The strength was found to increase with decreasing temperature, increasing strain rate (up to $5 \times 10^{-3} \mathrm{~s}^{-1}$ ) and increasing confining pressure at the lower temperatures. At $-11^{\circ} \mathrm{C}$, the strength at a strain rate of $5 \times 10^{-2} \mathrm{~s}^{-1}$ was lower than at $5 \times 10^{-3} \mathrm{~s}^{-1}$ probably because crack extension, leading to large-scale brittle fracture, is facilitated by the higher strain rate. The increase in strength with confining pressure was much more dramatic at the lower confining pressures, where frictional processes probably govern the behaviour, than at the higher pressures, where plastic processes probably dominate.

Four distinctive failure modes were evident and these occurred in well-defined regions of the temperature, strain rate and confining-pressure ranges. Remarkable strength-recovery behaviour was evident in the plastic/ shear-slip failure mode, where successive stick-slip load maxima often reached or exceeded previous ones in the same test.

Mean values of the strength of ice from the five different sources showed considerable variation. The data suggest that intragranular air bubbles play an important role in determining the uniaxial compressive strength of glacier and iceberg ice, and that this accounts for the observed differences in strength of the ice from the different sources.

\section{ACKNOWLEDGEMENTS}

The authors are grateful to many individuals who worked on the field and laboratory aspects of this research. In particular, we thank G. Dinn, presently at Consolidated Technologies Ltd, who served as technical manager of the Labrador ice-collection program, and Dr D. Nevel and J. Benoit who co-ordinated the work for Mobil Oil Canada, Ltd and assisted in the field work. Finally, we should like to thank Mobil Oil Canada, Ltd for the use of the data, and Hibernia Management and Development Company Ltd for assistance in providing the data.

\section{REFERENCES}

Arockiasamy, M., H. El-Tahan, A. S.J. Swamidas, W. Russell and D. V. Reddy. 1983. Semi-submersible response to bergy-bit impact. In Proceedings of the RINA Symposium on Semi-submersibles: The New Generation, London, March 17-18, 1983. Paper 14.

Barnes, P., D. Tabor and J. C. F. Walker. 1971. The friction and creep of polycrystalline ice. Proc. R. Soc. London, Ser. A., 324 (15.57), 127-15.5.

Budd, W.F. and T. H. Jacka. 1989. A review of ice rheology for ice sheet modelling. Cold Reg. Sci. Teclinol., 16 2), 107-144.
Cole, D. M. 1987. Strain-rate and grain-size effects in ice. J. Glaciol., $33(115), 274-280$.

Durham, W. B., H.C. Heard and S.H. Kirby. 1983. Experimental deformation of polycrystalline $\mathrm{H}_{2} \mathrm{O}$ ice at high pressure and low temperature: preliminary results. J. Geophys. Res., 88, Supplement, Part 1, B377 B392.

Duval, P., M.F. Ashby and I. Andermann. 1983. Rate-controlling processes in the creep of polycrystalline ice. F. Phys. Chem., $87(21)$, 40664074.

Ebinuma, T. and N. Maeno. 1992. Mechanical behaviors of polycrystalline ice containing pressurized gas enclosures. In Maeno, N. and T. Hondoh, eds. Physics and chemistry of ice. Sapporo, Hokkaido University Press, $428-433$.

Gagnon, R. E. 1994. Melt-layer thickness measurements during crushing experiments on fresh-water ice. J. Glaciol., 40 134), 119-124.

Gagnon, R. E. and P.H. Gammon. 1995. Characterization and flexural strength of iceberg and glacier ice. f. Glaciol., 41 (137), 103-111.

Gammon, P.H., R.E. Gagnon, W. Bobby and W. E. Russell. 1983. Physical and mechanical properties of icebergs. In Fifteenth Anmual Offshore Technology Conference, Houston. Texas, 2 - 6 May 1983. Proceedings. Vol. 1, 143-150.

Jones, S.J. 1982. The confined compressive strength of polycrystalline ice. J. Glaciol., 28 98), 171-177.

Lachance, J. and B. Michel. 1988. Experimental study of the brittle behaviour of iceberg ice. In Sackinger, W. M. and M. O. Jeffries, eds. Port and Ocean Engineering Under Arctic Conditions. Proceedings.] Volume III. Fairbanks, AK, University of Alaska, Geophysical Institute, 11-19.

Murrell, S. A. F., P. R. Sammonds and M. A. Rist. 1991. Strength and failure modes of pure ice and multi-year sea ice under triaxial loading. In Jones, S.J., R. F. McKenna, J. Tillotson and I.J. Jordaan, eds. Ice-Structure Interaction. IUTAM/IAHR Symposium, St. John's, Newfoundland, Canada, 1417 August 1989. Berlin, SpringerVerlag, 339-361.

Nadreau, J. P. and B. Michel. 1986. Yield and failure envelope for ice under multiaxial compressive stresses. Cold Reg. Sci. Technol., 13 (1), $75-82$.

Nadreau, J.-P. and B. Michel. 1987. Courbe intrinsèque de la glace en compression. J. Phys. (Paris), 48, Colloq. C1, 321-327. (Supplément au 3.)

Poplin, J.P. and T.D. Ralston. 1992. Physical and mechanical properties of Hobson's Choice Ice Island cores. Cold Reg. Sci. Technol., 20 2), 207-223.

Rist, M. A. and S. A.F. Murrell. 1994. Ice triaxial deformation and fracture. f. Glaciol., 40 (135), 305-318.

Sammonds, P. R., S. A. F. Murrell and M. A. Rist. 1989. Fracture of multi-year sea ice under triaxial stresses: apparatus description and preliminary results. J. Offshore Mech. Arct. Eng., 111, 258-263.

Schulson, E. M. 1990. The brittle compressive fracture of ice. Acta Metall. el Materialia, 38 10), 1963-1976.

Schulson, E. M. and N. P. Cannon. 1984. The effect of grain size on the compressive strength of ice. In International Association for Hydraulic Research. 7th International Symposium on Ice, Hamburg, August 27-31, 1984. Vol. 1. Hamburg, Hamburgische Schiflbau-Versuchsanstalt GmbH, 2938.

Schulson, E. M., D. E. Jones and G. A. Kuehn. 1991. The effect of confinement on the brittle compressive fracture of ice. Ann. Glaciol., 15, 216221.

Sinha, N.K. 1978. Rheology of columnar-grained ice. Exp. Mech., $1812,464470$.

Timco, G. W. and S. O'Brien. 1994. Flexural strength equation for sea ice. Cold Reg. Sci. Technol., 22 3), 285-298.

Toope, T. A., V. M. Arunachalam and D. B. Muggeridge. 1991. Effect of bubble concentration on the tensile creep and fracture of granular $\mathrm{T}_{1}$ ice. In Muggeridge, D. B., D. B. Colbourne and H. M. Muggeridge, eds. POAC91. The 11 th International Conference on Port and Ocean Engineering under Arctic Conditions, September 24 28, 1991, St. John's, [Proceedings.] Canada, Vol. 1. St. John's Ocean Engineering Research Centre, Memorial University of Newfoundland, 556-570. 